\title{
Assessment of growth and productivity of five peanut cultivars and genetic diversity using RAPD markers
}

\author{
Ghada M. Samaha', M. A. Ahmed ${ }^{1}$ and Asmaa R. Abd El-Hameid ${ }^{2 *}$ (D)
}

\begin{abstract}
Background: This study was conducted to evaluate the genetic diversity of five peanut cultivars grown under field conditions. A field experiment was conducted using five peanut cultivars (Giza-5, Giza-6, Ismailia-1, Gregory, and R92) in a randomized complete block design with five replications during two following seasons to estimate the performance of five peanut cultivars for vegetative growth, yield, and yield component traits as well as seed quality traits. Twenty RAPD primers were used to identify a unique fingerprint for each of five cultivars.
\end{abstract}

Results: Giza-6 cultivar surpassed all the tested peanut cultivars in the most vegetative growth traits and yield and its components traits, while the lowest values were observed in Giza- 5 cultivar. The dendrogram constructed from RAPD analysis showed that Gregory and Giza-5 were the most distant among five peanut cultivars.

Conclusions: RAPD markers are useful in the detection of genetic diversity of peanut. The availability of genetic diversity is important for the genetic improvement of peanut.

Keywords: Peanut, Yield components traits, Genetic diversity, RAPD-PCR

\section{Background}

Peanut (Arachis hypogea L.) is an important oil and protein crop, which is grown mainly in semi-arid tropic and sub-tropic areas of 109 countries around the world (Siva et al. 2014). Peanut contains about $50 \%$ oil, $25-30 \%$ protein, 20\% carbohydrates, and 5\% fiber and several other micronutrients and minerals (vitamin E, calcium, phosphorus, magnesium, zinc, riboflavin, and potassium) (Settaluri et al. 2012; Toomer 2018). The high-energy value, protein content, and minerals make peanut a rich source of nutrition at a comparatively low price. It has multipurpose uses of each plant part in direct consumption, cooking oil, and a rich source of protein for animal feed (Abou Kheira 2009; Akhtar et al. 2014).

The peanut crop grows in light soil and thrives in improving the characteristics of the newly reclaimed sandy soils which commonly suffer from some constraints such as poor physical properties and nutrients deficiency (Sabate 2003). Recently, peanut crop has been given great

\footnotetext{
* Correspondence: as_raafat4a@yahoo.com

${ }^{2}$ Botany Department, National Research Centre, Dokki, Giza, Egypt Full list of author information is available at the end of the article
}

attention due to its suitability for growth in the newly reclaimed sandy areas in Egypt. More than half of the national production is consumed directly without oil extraction and the remaining exported because of its high price in the international commodity market. It is successfully cultivated in the newly reclaimed sandy soils which commonly suffer from deficiency or unavailability of most the micronutrients (Ahmad and Rahim 2007). Increasing the growing area of oil seed crops out of the Nile valley is considered as a good way to reduce the competition with other main summer crops (maize, rice, and cotton). This approach is needed in increasing seed and oil production (Shaban et al. 2009).

Despite significant morphological variation in groundnut, the lack of variability at the genetic level is often cited as one of the reasons for little progress in genetic enhancement of the crop (Norden et al. 1982). The genetic diversity of peanut is important for their efficient use in breeding programs. Molecular marker analysis is a powerful tool for grouping of genotypes based on genetic distance data and for the selection of progenitors that might constitute new breeding populations (Westman and Kresovich 1997). 
Different techniques were used to determine genetic variation in plants including isozyme electrophoresis, and morphological traits, but these techniques are not considered as accurate markers due to environmental influences on morphological traits and insufficient polymorphism resulted among closely related cultivars (Matus and Hayes 2002). Molecular marker tools are helpful for the detection of genomic fragments contributing to the genetic diversity of a character and chosen of supreme genotypes. Marker analysis provides exact genotypic data, giving accuracy lacking with phenotypic measurements due to environmental interaction and experimental error (Altinkut et al. 2003).

Molecular markers minimize the time required to develop new genotypes with desirable traits and eliminate the need for chemical analysis phenotypic evaluation in the early generation breeding program. Among the molecular markers, random amplified polymorphic DNA (RAPD) is a rapid method for developing genetic maps and to determine DNA fragments to characterize peanut cultivars (Guo et al. 2005; Azzam et al. 2007; Eskandari et al. 2013). Application of RAPD markers in peanuts aid in determining the markers associated with genes controlling important traits. These molecular techniques assist in the identification of new and various sources of diversity which may aid breeders to choose what genotypes for creating new genetic combinations and to determine which genetic resources should be retained in a collection in order to conserve maximum genetic variation in the gene bank (Al-Saghir and Abdel-Salam 2015).

The objective of this study was to evaluate five peanut cultivars for growth and productivity and estimate the genetic diversity of five cultivars using RAPD markers.

\section{Materials and methods Field experiment}

Five peanut cultivars, namely Giza-5, Giza-6, Ismailia-1, Gregory, and R92 were used. This study was conducted at the Department of Genetics, Faculty of Agriculture, Ain Shams University, Shoubra El-Kheima, Egypt, and Field Crops Research Department of the National Research Centre, Dokki, Giza, Egypt. These five peanut cultivars were grown for two seasons in a randomized complete block design with five replications at the $\mathrm{Re}$ search and Production Station of the National Research Centre in El-Nubaria, Al-Beheira Governorate, Egypt, to evaluate the performance of these cultivars for vegetative growth, yield, and yield components as well as seed quality traits. Protein content was calculated by $N \% \times 6.25$ according to AOAC (2000). Oil content was estimated using a Soxhlet apparatus, while oil quality with respect to oleic acid and linoleic acid contents was estimated using gas chromatography according to AOCS (2012). Oleic to linoleic acid $(\mathrm{O} / \mathrm{L})$ ratio was calculated as the ratio of oleic acid to linoleic acid.

\section{Molecular genetic studies Genomic DNA extraction}

Total genomic DNA was extracted from dry seed of five peanut cultivars according to $\mathrm{Yu}$ et al. (2010). Approximately $0.2 \mathrm{~g}$ of dried seeds were placed into a $1.5-\mathrm{ml}$ tube with a $200 \mu \mathrm{l}$ of DNA extraction buffer $[10 \mathrm{mM}$ Tris- $\mathrm{HCl}$ (pH 7.6), 5 mM EDTA, 0.5\% SDS, 0.5\% NP-40, $0.5 \%$ Tween-20, $5 \mathrm{mg} / \mathrm{ml}$ PVP $40,80 \mu \mathrm{g} / \mathrm{ml}$ proteinase $\mathrm{K}$ ] and ground with a plastic pestle until a milky white solution or a paste was formed. The tube with homogenate was then incubated in a $55^{\circ} \mathrm{C}$ water bath for $20 \mathrm{~min}$ for cell lysis and protein digestion. After digestion was completed, a $200 \mu \mathrm{l}$ of phenol-chloroform-isoamylol (25: $24: 1, \mathrm{~V} / \mathrm{V} / \mathrm{V})$ was added to the tube to remove proteinase $K$. After centrifugation at $9,000 \times g$ for $5 \mathrm{~min}$, the supernatant was collected $(\sim 150 \mu \mathrm{l})$ in a sterile Eppendorf tube with an equal volume of isopropanol. The mixture was gently mixed and centrifuged at $10,000 \times g$ for 2 min to precipitate the DNA. The dried DNA pellets were then dissolved in a $150 \mu \mathrm{l}$ of TE buffer.

\section{RAPD-PCR analysis}

PCR reactions were performed according to Williams et al. (1990) using 20 arbitrary 10-mer primers (Table 1). The reaction conditions were optimized and mixtures (25 $\mu$ l total volume) contained $2 \mu$ l of DNA template (25 $\mathrm{ng} / \mu \mathrm{l}), 2 \mu \mathrm{l}$ of primer, $0.5 \mu \mathrm{l}$ of dNTPs $(2.5 \mathrm{mM}), 2.5 \mu \mathrm{l}$ of $\mathrm{Mgcl}_{2}(2.5 \mathrm{mM}), 2.5 \mu \mathrm{l}$ of $10 \mathrm{X}$ buffer, Taq DNA polymerase $(1 \mathrm{U} / \mu \mathrm{l})$, and $\mathrm{H} 2 \mathrm{O}$ up to $25 \mu \mathrm{l}$. Amplification was carried out in a Primus Thermocycler, which was programmed for 37 cycles as follows: denaturation at $94{ }^{\circ} \mathrm{C} /$ $2 \mathrm{~min}$ (one cycle), annealing at $37^{\circ} \mathrm{C} / 1 \mathrm{~min}$, extension at $72{ }^{\circ} \mathrm{C} / 2 \mathrm{~min}$ ( 35 cycles), final extension at $72^{\circ} \mathrm{C} / 10 \mathrm{~min}$ (one cycle), and then kept at $4{ }^{\circ} \mathrm{C}$ until use. Agarose gel (1.5\%) electrophoresis was used for separating the PCR products. The run was performed at $100 \mathrm{~V}$ for about $1 \mathrm{~h}$. The DNA marker used in this study was $1 \mathrm{~kb}$ DNA ladder

Table 1 List of used primers and their nucleotide sequences for RAPD-PCR analysis

\begin{tabular}{llll}
\hline Primer $($ OP-) & Sequence $\left(5^{\prime} \rightarrow 3^{\prime}\right)$ & Primer $\left(\mathrm{OP}_{-}\right)$ & Sequence $\left(5^{\prime} \rightarrow 3^{\prime}\right)$ \\
\hline A01 & CAGGCCCTTC & B01 & GTTTCGCTCC \\
A02 & TGCCGAGCTG & B03 & CATCCCCCTG \\
A03 & AGTCAGCCAC & B06 & TGCTCTGCCC \\
A05 & AGGGGTCTTG & B08 & GTCCACACGG \\
A07 & GAAACGGGTC & B10 & CTGCTGGGAC \\
A08 & GTGACGTAGG & D04 & TCTGGTGAGG \\
A09 & GGGTAACGCC & O11 & GACAGGAGGT \\
A16 & AGCCAGCGAA & O14 & AGCATGGCTC \\
A17 & GACCGCTTGT & O15 & TGGCGTCCTT \\
A19 & CAAACGTCGG & Z12 & TCAACGGGAC \\
\hline
\end{tabular}


which consists of ten different DNA fragments (1000, 900, $800,700,600,500,400,300,200$, and $100 \mathrm{bp}$ ).

\section{Statistical analysis}

The collected data for these four traits from five peanut cultivars were statistically analyzed using analysis of variance (ANOVA) procedure according to Snedecor and Cochran (1969). The differences among means were compared using Duncan's new multiple ranges test (Duncan 1955). The correlation coefficient was used to determine the relationship between oil content and protein content. All fragments resulting from RAPD gels were detected on an UV transilluminator filter and photographed under UV light with Polaroid film 667 and scanned with Bio-Rad video densitometer Model 620 at a wavelength of 577. The gel image was analyzed using the Total lab TL 120 to determine the molecular sizes of the amplified fragments. The amplified fragments were scored as present (1) or absent (0).

\section{Results}

Field experiment

Vegetative growth traits

Analysis of variance for most vegetative growth traits revealed significant variations among five peanut cultivars. Their means are summarized in Table 2, except the leaf area index (LAI) trait did not record significant differences in both seasons. The number of branches/plant trait revealed significant variations in the first season only. On the other hand, crop growth rate (CGR) grams/ day trait revealed significant variations in the second season only.

These results indicated that the Giza- 6 cultivar surpassed all the tested peanut cultivars in most of the vegetative growth traits, except the plant height and leaf area traits. This may be due to the increase in the efficiency of Giza- 6 cultivar to photosynthate more metabolites as well as increasing cell division and absorption of more water and minerals from soil. This reflected on increasing the production of more sizable organs.

\section{Yield and yield components traits}

Analysis of variance for yield and most yield components traits revealed significant variations among five peanut cultivars (Table 3), except the number of seeds/pod and migration coefficient traits did not record significant differences in both seasons.

\section{Seed quality determination}

\section{Protein content (percentage)}

Analysis of variance for protein content trait revealed significant variations among five peanut cultivars (Table 4). Means of protein content trait values were significantly varied among five peanut cultivars, which ranged from 28.5 and $28.6 \%$ for Giza-5 cultivar to 21.5 and $22.9 \%$ for Gregory cultivar in both seasons, respectively. This means that the Giza-5 cultivar is the highest one for protein content.

\section{Oil content (percentage)}

Analysis of variance for oil content trait revealed significant variations among five peanut cultivars which are summarized in Table 4.

The means of oil content trait values for all cultivars in the first season were higher than the second season. The mean of oil content trait values was significantly varied among five peanut cultivars, which ranged from 53.3 and $52.8 \%$ for Gregory cultivar to 45.2 and $45.1 \%$ for Giza-5 cultivar in the two seasons, respectively. This result showed that Gregory cultivar contained the highest oil content.

\section{Fatty acids composition (percentage)}

Oil quality trait is determined by its fatty acids composition. Analysis of variance for fatty acids composition revealed some significant variations among five peanut cultivars which summarized in Table 4 . There were no significant variations among five peanut cultivars formyristic acid, arachidic acid, and TS/TU ratio in the second season and palmitoleic acid in the first season.

These results confirmed that oleic acid was the major component (40.2-57.7\%) of total fatty acids, followed by linoleic acid (22.6-32.9\%). The total saturated fatty acids ranged from 18.9 for Giza-5 cultivar to 21.4 for Giza-6 cultivar, while the total unsaturated fatty acids ranged from 68.1 for R92 cultivar to 84.59 for Gregory cultivar. It was clear that the highest values of oleic acid content $(57.7,56.3 \%)$ and $\mathrm{O} / \mathrm{L}$ ratio $(2.6,2.1)$ were recorded by the Gregory cultivar in the two seasons, although this cultivar gave the lowest linoleic acid content (22.6, 27.1 $\%)$ in the two seasons. Gregory cultivar was more suitable for oil quality as compared with the other cultivars. By contrast, Giza- 6 cultivar showed a high level of linoleic acid (32.2, 32.9\%), and Gregory cultivar was more suitable for cooking.

\section{RAPD-PCR analysis}

DNA isolated from five peanut cultivars was tested against 20 primers. Out of these primers, nine primers did not reveal any polymorphism, while 11 primers revealed a polymorphism with five peanut cultivars as shown in Fig. 1.

Eleven RAPD primers OP-A02, OPA-05, OP-A16, OPA17, OP-A19, OP-B03, OP-B06, OP-B10, OP-O14, OP$\mathrm{O} 15$, and OP-Z12 produced different banding patterns for all cultivars. While nine primers OP-A01, OP-A03, OP-A07, OP-A08, OP-A09, OP-B01, OP-B08, OP-D04, and $\mathrm{OP}-\mathrm{O} 11$ detected no polymorphism, although they did successfully amplify a range of monomorphic bands. 


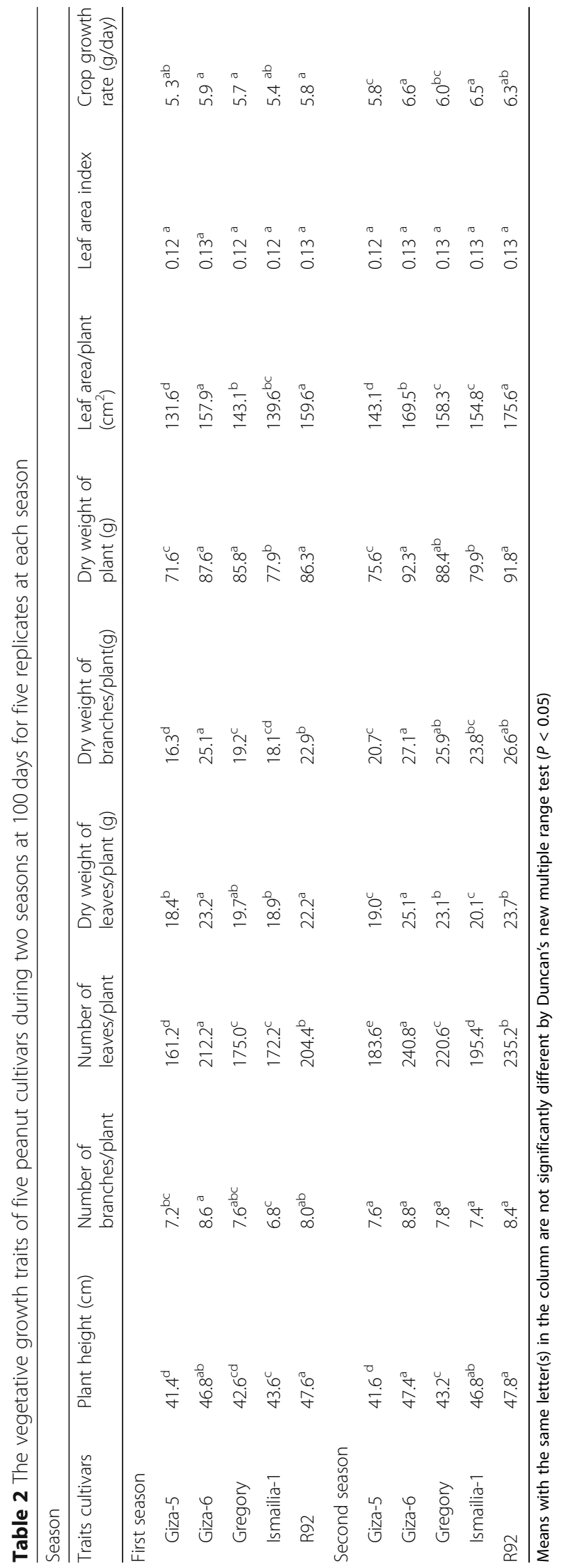




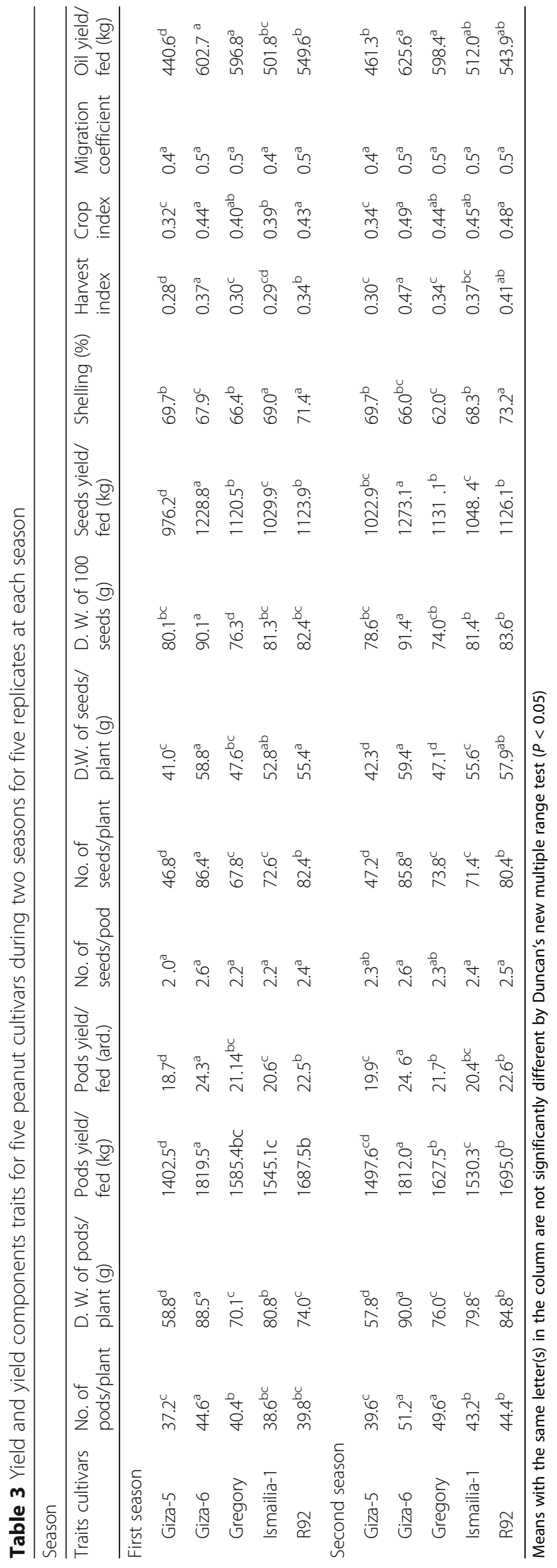




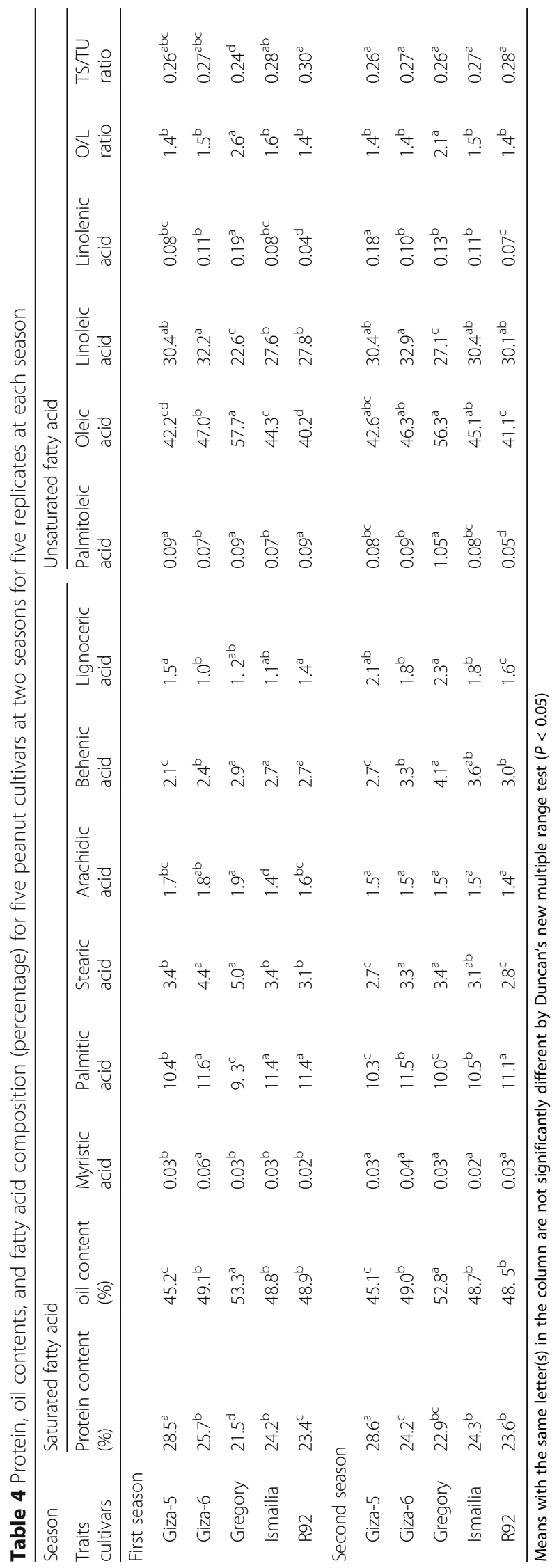




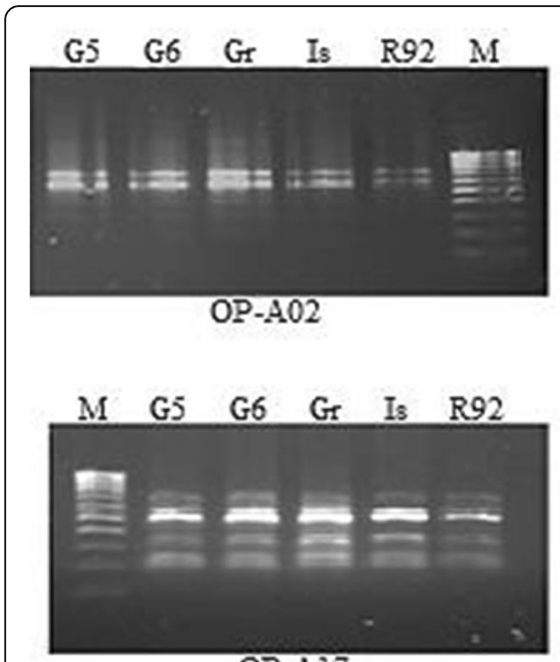

OP-A17

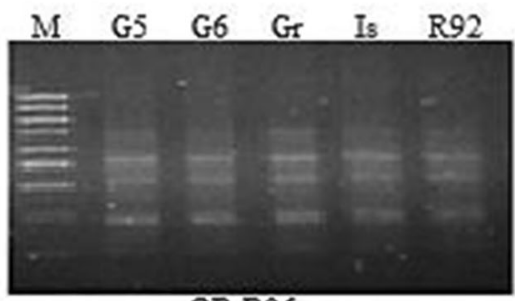

OP-B06

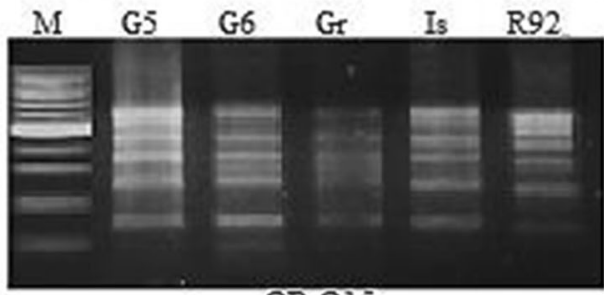

OP-O15

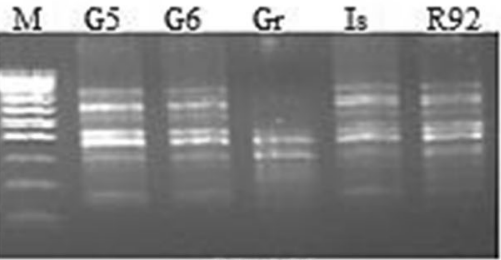

OP-A05

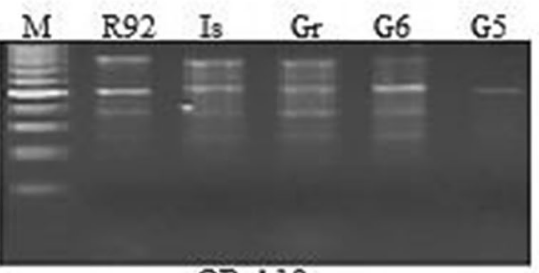

OP-A19

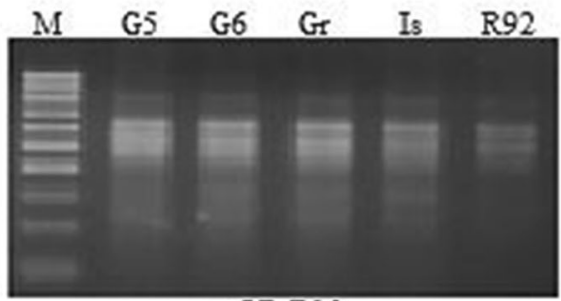

OP-B10

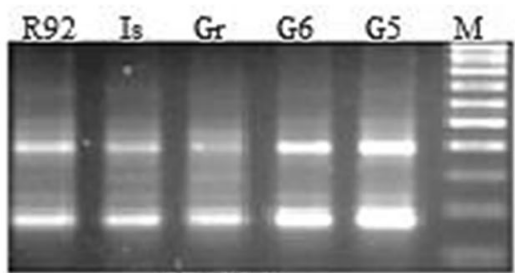

OP-A16

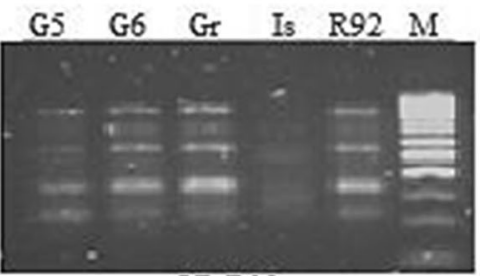

OP-B03

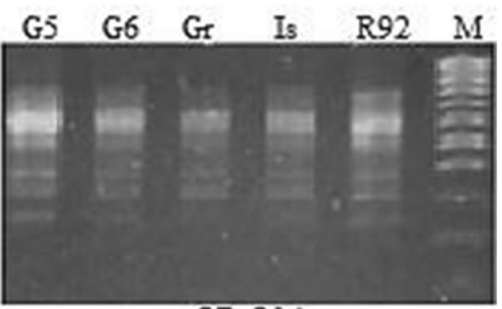

OP-014

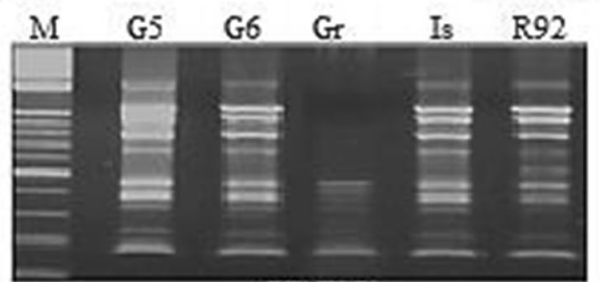

OP-Z12

Fig. 1 RAPD-PCR fragments of the 11 primers with five peanut cultivars. M marker, G5 Giza-5, G6 Giza-6, Gr Gregory, Is Ismailia-1 and R92

The eleven primers produced a total number of 82 fragments, with an average of seven fragments per primer ranging from five fragments with primers OP-A02, OP-A17, OP-B06, and OP-B10 to17 fragments with OPZ12 primer. However, these fragments were not presented in all cultivars. The polymorphism percentages were ranged from $20.00 \%$ to $87.50 \%$ with an average of $54.80 \%$. The OP-A19 primer showed the highest level of polymorphism $87.50 \%$, while the OP-A17 and OP-B06 primers showed the lowest level $20.00 \%$ (Table 5).

The genetic similarity matrix values (Table 6) based on RAPD markers were ranged from 0.91 between Ismailia-1 and R92 cultivars to 0.71 between Giza- 5 and Gregory cultivars.

Based on the data of RAPD markers, the constructed dendrogram divided these cultivars into two main clusters (Fig. 2); the first one included only Giza-5 cultivar. The other cluster was divided into two main sub- clusters; the first one included only the Gregory cultivar, while the other one was divided into two sub-sub clusters, the first one included only the Giza- 6 cultivar, while the second one included Ismailia1 and R92 cultivars.

According to RAPD analysis, these results indicated that the most closely related cultivars were Ismailia1 and R92, which were located in the same sub-sub cluster, while the most dissimilar cultivars were Giza-5 and Gregory, which located in the two different main clusters.

\section{Discussion}

\section{Field experiment}

From the previous results (Tables 2 and 3), it is clear that Giza- 6 cultivar surpassed all the tested peanut cultivars in vegetative growth, yield, and its most components traits. The obtained results were in a good line with those obtained by El-Saady et al. (2014), Meena et al. (2014), Mahrous et al. (2015), and Sarkees (2015). 
Table 5 The number of total amplified fragments, polymorphic fragments, polymorphism percentage, and specific markers using RAPD analysis

\begin{tabular}{|c|c|c|c|c|c|c|c|c|c|}
\hline Primer no. & Primer name & TAF & PF & MF & UF & P \% & Band no. & MS (bp) & Cultivars \\
\hline 1 & OP-A02 & 5 & 3 & 2 & 0 & 60.00 & - & - & - \\
\hline 2 & OP-A05 & 9 & 5 & 4 & 1 & 55.56 & 8 & 241 & Gregory \\
\hline 3 & OP-A16 & 6 & 2 & 4 & 0 & 33.33 & - & - & - \\
\hline 4 & OP-A17 & 5 & 1 & 4 & 0 & 20.00 & - & - & - \\
\hline 5 & OP-A19 & 8 & 7 & 1 & 1 & 87.50 & 5 & 593 & R92 \\
\hline \multirow[t]{2}{*}{6} & OP-B03 & 7 & 4 & 3 & 2 & 57.14 & 4 & 451 & Ismailia-1 \\
\hline & & & & & & & 6 & 235 & Ismailia-1 \\
\hline 7 & OP-B06 & 5 & 1 & 4 & 0 & 20.00 & - & - & - \\
\hline 8 & OP-B10 & 5 & 2 & 3 & 0 & 40.00 & - & - & - \\
\hline 9 & OP-O14 & 6 & 2 & 4 & 0 & 33.33 & - & - & - \\
\hline \multirow[t]{2}{*}{10} & OP-O15 & 9 & 4 & 5 & 2 & 44.44 & 6 & 293 & Giza-6 \\
\hline & & & & & & & 9 & 105 & Giza-6 \\
\hline \multirow[t]{4}{*}{11} & OP-Z12 & 17 & 9 & 8 & 4 & 52.94 & 2 & 1464 & Giza-6 \\
\hline & & & & & & & 8 & 588 & R92 \\
\hline & & & & & & & 11 & 413 & Gregory Giza-6 \\
\hline & & & & & & & 15 & 265 & \\
\hline Total & & 82 & 40 & 42 & 10 & & & & \\
\hline
\end{tabular}

TAF total amplified fragments, PF polymorphic fragments, MF monomorphic fragments, UF unique fragments, MS molecular size, $P \%$ polymorphism percentage

On the other hand, these results were not agreed with Abdalla et al. (2009) who found that Giza-5 cultivar was superior to Giza-6 cultivar in plant height, number of branches/plant, number of pods/plant, and a 100-pod weight trait.

Also, these results are confirmed by El-Saady et al. (2014) who showed that Giza-6 cultivar surpassed Giza-5 cultivar in most of the yield and its components traits. The superiority of Giza- 6 cultivars may be due to its high ability to grow under El-Nubaria conditions. This means that the Giza- 6 cultivar was the best one for the production of seeds and pods yield kilograms/fed. Moreover, differences among five peanut cultivars may be due to the differences in their genetic make-up and their response to the environmental conditions.

Table 6 The genetic similarity matrix of five peanut cultivars based on RAPD markers

\begin{tabular}{llllll}
\hline Cultivars & Giza-5 & Giza-6 & Gregory & Ismailia-1 & R92 \\
\hline Giza-5 & 1.00 & & & & \\
Giza-6 & 0.81 & 1.00 & & & \\
Gregory & 0.71 & 0.82 & 1.00 & & \\
Ismailia-1 & 0.76 & 0.86 & 0.85 & 1.00 & \\
R92 & 0.79 & 0.84 & 0.81 & 0.91 & 1.00 \\
\hline
\end{tabular}

\section{Seed quality determination}

The previous results (Table 4) are confirmed by Newase et al. (1990) and Tomar et al. (1995) who found differences among four peanut cultivars in protein content of seed was significant. Abdalla et al. (2009) found that Giza-5 cultivar was superior to Giza-6 cultivar in protein content trait. Mahrous et al. (2015) found that Giza-5 cultivar was superior to Gregory in protein content trait. As discussed by Migawer et al. (2001), El-Saady et al. (2014) found significant differences among some tested cultivars concerning seed oil and protein contents traits. Similar results were obtained by Mahrous et al. (2015) who found that Gregory cultivar showed the highest seed oil content (52.22\%). Also, Gulluoglu et al. (2016) found that oil content of peanut cultivars varied between 46.96 and $51.55 \%$ based on dry weight of seeds and the highest oil content value (51.55\%) was reported in Georgia Green cultivar, while the lowest one $(46.96 \%)$ was noticed in Flower-22 cultivar.

Both the seed oil and protein content traits are often influenced by the environment. Correlation coefficients between protein and oil contents (- 0.013) revealed a negative significant correlation. These results are similar to Selvaraj et al. (2009) and Sarvamangala et al. (2011) who found that the relationship between oil content was inverse to that of protein content. Moreover, Chun et al. (2014) showed a 


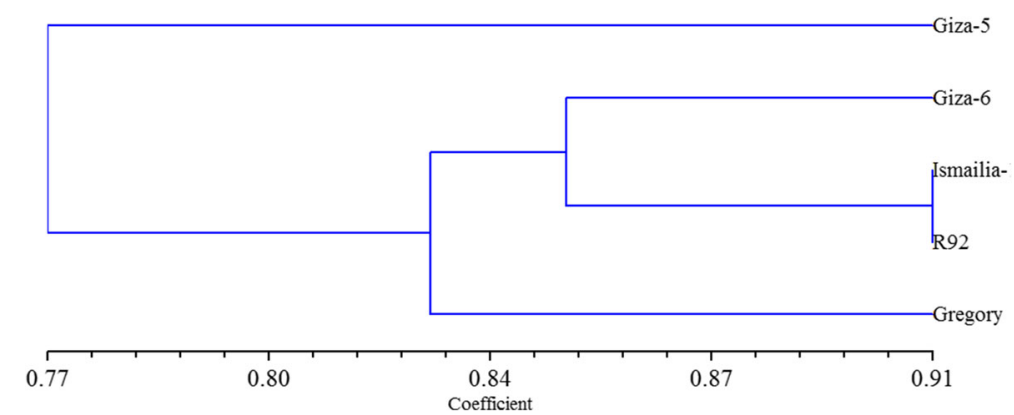

Fig. 2 Dendrogramtree of genetic distances among five peanut cultivars based on RAPD markers

significant negative correlation of the oil content with the protein content which was found in the tested cultivars.

Oils with a higher percentage of unsaturated fatty acids can be heated to high temperatures without smoking, leading to faster cooking time and absorption of less oil. High $\mathrm{O} / \mathrm{L}$ in peanut is favored over low $\mathrm{O} / \mathrm{L}$ because it confers health benefits and oil stability (Miller et al. 1987; Wilson et al. 2006).

Many investigators found significant variations among peanut cultivars in growth, productivity, and quality due to the variation in their genetics and their interaction with the environmental condition (Meena et al. 2014; Mahrous et al. 2015; Sarkees 2015).

\section{RAPD-PCR analysis}

This study described the genetic diversity using RAPD markers. The highest number of markers was observed in Giza-6, which recorded four unique markers at 293 bp and $105 \mathrm{bp}$ of primer OP-O15 and $1464 \mathrm{bp}$ and 265 of primer OP- Z12. Also Gregory has two unique markers, bands at 241 bp of primer OP-A05 and bands at $413 \mathrm{bp}$ of primer OP-Z12. Ismailia- 1 has two unique markers at 451 and $235 \mathrm{bp}$ of primer OP-B03. R92 has two unique markers at $593 \mathrm{bp}$ of primer OP-A19 and $588 \mathrm{bp}$ of primer OP-Z12. On the other hand, Giza-5 did not reveal any unique marker. These results confirmed that the selected RAPD markers are dispersed in the peanut genome and may be valuable to study the genetic diversity of five peanut cultivars. These results agreed with Guo et al. (2005) and Lang and Hang (2007) who reported that the distinctive RAPD patterns generated from peanut cultivars could be used as genomic fingerprint to establish the identity of a given genotype. Similarly, Al-Saghir and Abdel-Salam (2015) observed that the technique of RAPD could be used to detect the genetic diversity in peanut and give a successful fingerprinting of peanut using these markers. Lom and Rao (2015) indicated the efficacy of RAPD markers for detecting the genetic variability in the wild Musa acuminate.
The low level of polymorphism might be due to the low molecular diversity among the peanut cultivars, and this is because cultivated peanut has a narrow genetic base which originated from a single and recent polyploidization event. This was in agreement with the previous findings as low level of polymorphism among cultivated groundnut (Hopkins et al. 1999; Herselman 2003; Moretzsohn et al. 2004; Mace et al. 2006). On the other hand, in our study, the polymorphism percentage $(54.80 \%)$ increased compared to Dwivedi et al. (2001) who found about $18.74 \%$ of polymorphism among selected peanut cultivars using the same RAPD technique.

The genetic similarity matrix results are in harmony with those obtained by Dwivedi et al. (2001) who reported that the genetic similarity values among selected groundnut germplasm were ranged from $59.0 \%$ to 98.8 $\%$ with an average of $86.2 \%$. NaguibNemat et al. (2011) reported that the genetic similarity among peanut cultivars ranged from 0.68 to 0.92 with an average of 0.8 .

\section{Conclusions}

This study showed that Giza-6 cultivar surpassed all tested peanut cultivars in the most traits, while the lowest values were observed in Giza-5 cultivar. Gregory cultivar was more suitable for oil quality as compared with the other cultivars. The results showed that RAPD markers were distributed in the peanut genome and may be useful to detect the genetic diversity of these five peanut cultivars. The results obtained in this study may assist peanut cultivation and in peanut breeding programs.

\section{Abbreviations \\ Bp: Base pair; DNA: Deoxyribonucleic acid; dNTP: Deoxy nucleoside triphosphate; EDTA: Ethylene diamine tetra acetic acid; HI: Harvest index; Mb: Mega base pairs = 1,000,000 bp; $\mathrm{MgCl}_{2}$ : Magnesium chloride; MS: Molecular size; MT: Marker type; O/L: Oleic to linoleic acid ratio; PCR: Polymerase chain reaction; PVP: PolyvinylpyrrolidoneRAPDRandom amplified polymorphic DNA; TAF: Total amplified fragmentsTBETris-borate- EDTA; TE: Tris-EDTA}

\section{Acknowledgements}

The authors wish to thank to all the staff members of Genetics Dept., Faculty of Agric., Ain Shams Univ., Field Crops Research Department, and Botany 
Department of the National Research Centre for their excellent technical assistance.

\section{Authors' contributions}

GS performed and analyzed this study and was a major contributor in writing the manuscript. MA was a contributor in writing and processing the manuscript. AR was a contributor in analyzing the data. All authors read and approved the final manuscript."

\section{Funding}

Not applicable

\section{Availability of data and materials}

All data and materials of the study have been presented in the main manuscript.

\section{Ethics approval and consent to participate}

The authors declare that the work is ethically approved, and consent to participate was obtained.

\section{Consent for publication}

The authors declare that the work has been consented for publication.

\section{Competing interests}

The authors declare that they have no competing interests.

\section{Author details}

${ }^{1}$ Field Crops Research Department, National Research Centre, Dokki, Giza, Egypt. ${ }^{2}$ Botany Department, National Research Centre, Dokki, Giza, Egypt.

Received: 8 August 2019 Accepted: 24 September 2019

Published online: 02 December 2019

\section{References}

Abdalla AA, El-Howeity MA, Desoky AH (2009) Response of peanut crop cultivated in newly reclaimed soil to inoculation with plant growthpromoting Rhizobacteria. Minufiya J Agric Res 34:2281-2304

Abou Kheira AA (2009) Macro management of deficit irrigated peanut with sprinkler irrigation. Agri Water Manage 96:1409-1420

Ahmad N, Rahim M (2007) Evaluation of promising groundnut, (Arachis hypogaea L.) varieties for yield and other characters. J Agric Res 45:185-189

Akhtar S, Khalid N, Ahmed I, Shahzad A, Suleria HAR (2014) Physicochemical characteristics, functional properties, and nutritional benefits of peanut oil. $J$ Crit Rev Food Sci Nutr 54:1562-1575

Al-Saghir MG, Abdel-Salam ASG (2015) Genetic diversity of peanut (Arachis hypogea L.) cultivars as revealed by RAPD markers. Am J Plant Sci 6:2303-2308

Altinkut A, Kazan K, Gozukirmizi N (2003) AFLP marker linked to water-stresstolerant bulks in barley (Hordeum vulgare L.). Genet Mol Biol 26:77-82

AOAC (2000) In Official Methods of Analysis of AOAC. International. $17^{\text {th }}$ ed. Washington DC 41:66-68

AOCS (2012) In Official Methods and Recommended Practices of the American Oil Chemists' Society. $4^{\text {th }}$ ed, Champaign. IL USA 1:92-100

Azzam CR, Azer SA, Khaleifa MM, Abol-Ela MF (2007) Characterization of peanut mutants and molecular markers associated with resistance to pod rot diseases and aflatoxin contamination by RAPD and ISSR. Arab J Biotech 10:301-320

Chun LI, Hongme ML, Zhang TW, Han X, Zhang H (2014) Association mapping of seed oil and protein content in Sesamum indicum L. using SSR markers. PLOS One 9:105-117

Duncan DB (1955) Multiple ranges and multiple F test. In Biometrics 11:1-24

Dwivedi SL, Gurtu S, Chandra S, Yuejin W, Nigam SN (2001) Assessment of genetic diversity among selected groundnut germplasm. I. RAPD analysis. Plant Breeding 120:345-349

El-Saady AM, El-Sayed AA, Tellep WMAK, El-Dahshour MF (2014) Response of some peanut (Arachis hypogaea L.) cultivars grown in sandy soil to soil and foliar feeding with the different sources of phosphorus. Inter J of Plant and Soil Sci 3:523-537

Eskandari M, Cober ER, Rajcan I (2013) Genetic control of soybean seed oil: I. QTL and genes associated with seed oil concentration in RIL populations derived from crossing moderately high-oil parents. Theor Appl Genet 126:483-495
Gulluoglu L, Bakal H, Onat B, EL-Sabagh A, Arioglu H (2016) Characterization of peanut (Arachis hypogaea L.) seed oil and fatty acids composition under different growing season under mediterranean environment. J Exp Biol Agric Sci 4:564-571

Guo B, Holbrook C, He G, Culbreath A, Kvien C (2005) Identification and characterization of molecular markers associated with resistance to TSWV and leaf spots in peanuts. Planta 223:512-520

Herselman L (2003) Genetic variation among Southern African cultivated peanut (A. hypogaea L.) genotypes as revealed by AFLP analysis. Euphytica 133:319-327

Hopkins MS, Casa AM, Wang T, Mitchell SE, Dean RE, Kochert GD, Kresovich S (1999) Discovery and characterization of polymorphic simple sequence repeats (SSRs) in peanut. Crop Sci 39:1243-1247

Lang NT, Hang PTC (2007) Genetic divergence analysis on peanut by RAPD. Omonrice 15:174-178

Lom A, Rao SR (2015) Efficacy of RAPD, ISSR and DAMD markers in assessment of genetic variability and population structure of wild Musa acuminate colla. Physiol Mol Biol Plants 21:349-358

Mace ES, Phong DT, Upadhyaya HD, Chandra S, Crouch JH (2006) SSR analysis of cultivated groundnut (Arachis hypogaea L.) germplasm resistant to rust and late leaf spot diseases. Euphytica 152:330-335

Mahrous NM, Safina SA, Abo Taleb HH, El-Behlak SM (2015) Integrated use of organic, inorganic and bio fertilizers on yield and quality of two peanut (Arachis hypogaea L.) cultivars grown in a sandy saline soil. Am Eurasian J Agric Environ Sci 15:1067-1074

Matus IA, Hayes PM (2002) Genetic diversity in three groups of barley germplasm assessed by simple sequence repeats. Genome 45:1095-1106

Meena RS, Yadav RS, Meena VS (2014) Response of groundnut (Arachis hypogaed L.) varieties to sowing dates and NP fertilizers under western dry zone of India. Bangladesh J Bot 43:169-173

Migawer EA, Soliman MS, Mona AM (2001) Performance of two peanut cultivars and their response to NPK fertilization in newly reclaimed loamy sandy soil. $J$ Agric Sci Mansoura Univ 26:6653-6667

Miller JF, Zinnerman DC, Vick BA (1987) Genetic control of high oleic acid content of sunflower oil. Crop Science 27:923-926

Moretzsohn MC, Hopkins C, Mitchell MS, Kresovich SE, Valls JFM, Ferreira ME (2004) Genetic diversity of peanut (Arachis hypogaea L.) and its wild relatives based on the analysis of hyper variable regions of the genome. BMC Plant Biol 4:11-19

NaguibNemat A, Abd-Elaal ANA, Samar WA, El Shakhess AM (2011) Variability, seed testing, genetic parameters, chemical composition and protein banding of ten peanut genotypes. Egypt J Plant Breed 15:187-211

Newase VB, Wagh RG, Thorat ST, Pati BP (1990) Production potential and economics of promising groundnut genotypes under varying levels of phosphorus in Konkan. J Indian Soc Coastal Agric Res 8:31-35

Norden AJ, Smith OD, Gorbet DW (1982) Breeding of the cultivated peanut. In: Pattee HE, Young CT (eds) Peanut Science and Technology. American Peanut Research and Education Society, Inc, Yoakum, pp 95-122

Sabate J (2003) Nut composition and body weight. Am J Clin Nutr. 78:647-650

Sarkees NA (2015) Effect of sowing dates on development, seed yield and quality of some peanut (arachis hypogaea I.) genotypes. Jordan J Agric Sci 11:67-80

Sarvamangala C, Gowda MVC, Varshney RK (2011) Identification of quantitative trait loci for protein content, oil content and oil quality for groundnut (Arachis hypogaea L.). Field Crops Res 122:49-59

Selvaraj MG, Narayana M, Schubert AM, Ayers JL, Baring MR, Burow MD (2009) Identification of QTLs for pod and kernel traits in cultivated peanut by bulked segregant analysis. Electron J Biotechnol 12:91-100

Settaluri VS, Kandala CVK, Puppala N, Sundaram J (2012) Peanuts and their nutritional aspects-a review. Food Nutr Sci 3:1644-1650

Shaban SA, Abu-Hagaza NM, Mahrous NM, El-Hameed MHA (2009) Effect of planting dates, hill-spacings and harvest dates on yield and quality of the new released peanut cultivar Giza 6. Egypt J of Agron 31:39-54

Siva G, Kamalakkannan K, Sivakumar S, Premkumar G, Gurusaravanan P, Vinoth S, Jayabalan N (2014) Analysis of genetic variability in Arachis hypogaea L. Using RAPD markers. J Swamy Bot Club 31:29-36

Snedecor CW Cochran WG (1969) In statistical methods $6^{\text {th }}$ ed. lowa State Univ. Press, Ames, Lowa, USA, pp 132-143

Tomar RAS, Kushwaha HS, Singh V (1995) Response of groundnut to phosphorus and zinc grown in alluvial soil. Agric Sci Digest 15:64-68

Toomer OT (2018) Nutritional chemistry of the peanut (Arachis hypogaea). Critical reviews in food science and nutrition 58(17):3042-3053

Westman AL, Kresovich S (1997) Use of molecular markers techniques for description of plant genetic variation. In: Callow JA, Ford-Lloyd BV, Newbury 
HJ (eds) Plant Genetic Resources: Conservation and Use. CAB International, Wallingford, UK, pp 9-48

Williams JGK, Kubelik AR, Livak KJ, Rafalski JA, Tingey SV (1990) DNA polymorphisms amplified by arbitrary primers are useful as genetic markers. Nucl Acids Res 18:6531-6535

Wilson K, Yang H, Seo CW, Marshall WE (2006) Select metal adsorption by activated carbon made from peanut shell. Bio-resource Technol 97:2266-2270

Yu ST, Wang CT, Yu SL, Wang XZ, Tang YY, Chen DX, Zhang JC (2010) Simple method to prepare DNA templates from a slice of peanut cotyledonary tissue for Polymerase Chain Reaction. Electron J Biotechnol 71:3431-3458

\section{Publisher's Note}

Springer Nature remains neutral with regard to jurisdictional claims in published maps and institutional affiliations.

\section{Submit your manuscript to a SpringerOpen ${ }^{\circ}$ journal and benefit from:}

- Convenient online submission

- Rigorous peer review

- Open access: articles freely available online

- High visibility within the field

- Retaining the copyright to your article

Submit your next manuscript at $\boldsymbol{\nabla}$ springeropen.com 